
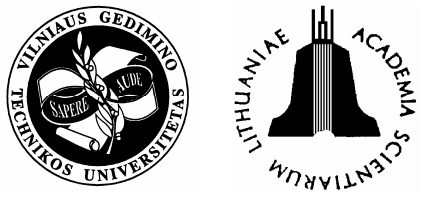

\title{
A TOOL FOR MODAL ANALYSIS OF LAMINATED BENDING PLATES
}

\author{
Edvard Michnevič \\ Dept of Engineering Mechanics, Vilnius Gediminas Technical University, \\ Saulètekio al. 11, LT-10223 Vilnius, Lithuania. \\ E-mail:edmich@fm.vtu.lt
}

Received 20 June 2006; accepted 8 Sept 2006

\begin{abstract}
A new finite element for modelling laminated bending plates was defined based on the effective triangular finite element of the discrete Kirchhoff's theory. The plates can be made of layers arranged in any order and consisting of different but orthotropic materials. The suggested finite element has 6 degrees of freedom in every node, i e 3 linear displacements and 3 rotations about the axis of coordinates. A mathematical model of the element describes stress and strain effects both in the plane of the element or perpendicular to it, except for shear. The suggested element can be used for calculating laminated plates or beams, not subjected to heavy shear stresses. Some numerical case studies are provided, while the results obtained are compared with the well-known analytical and numerical solutions.
\end{abstract}

Keywords: laminates, composites, composite structures, layered plates, linear analysis, non-linear analysis, finite element.

\section{Introduction}

Modern production technologies are used for manufacturing various composite materials. Composites, due to their outstanding mechanical properties, relatively low weight and a possibility to predetermine their_characteristics, are widely used not only in high-tech areas, but in civil engineering as well. According to their structural and design characteristics, composite materials can be subdivided into reinforced materials shaped in various metal or non-metal moulds and laminated or layered structures obtained by combining layers of various materials. Therefore, the development of structures made of composite materials largely depends on the ability to model them.

It is hardly possible to review modelling problems associated with all available composite materials, therefore, the present paper addresses only the problems of modelling laminated bending plates. Though laminated structures are widely used, the theories of non-linear deformation and failure of modern layered composites as well as methods of mathematical modelling have not been fully developed and presented in detail yet. Because of anisotropic nature of laminated structures, all tensioncompression and bending effects as well as the interaction of bending-membrane and membrane-shear effects should be considered [1-4]. Therefore, only a few assumptions simplifying the stress-strain state for the problems associated with the analysis of thin-wall bending plates can be applied.

A wide variety of finite elements are available for the analysis of structures made of commonly used materials. However, the problems associated with laminated twin-wall bending plates require a special kind of layered finite elements. Precise finite elements [5-9] are often hardly realisable in application programs due to the complexity of a mathematical model. Therefore, the need for sufficiently accurate, efficient and applicable finite elements to be used in laminated bending plates, which do not require any cross-section symmetry, still remains.

In the present paper, new types of matrix expressions allowing for evaluation of all above-mentioned membrane and bending effects are offered for the laminated anisotropic triangular finite element DKT_CST [10]. This finite element can be used for modelling anisotropic laminated bending plates consisting of layers of orthotropic material arranged in any order, as well as the particular zones of similar plates or beams, when shear deformations are insignificant.

\section{Mathematical modelling of problems}

A finite element may be considered to be completely defined, when it is applied to solve linear and non-linear static problems as well as modal analysis [11] and its accuracy is determined, because all characteristic structural matrices of the element should be generated for these problems. Below mathematical models of the considered problems are provided.

The following equation applies to a linear system of finite elements:

$$
\left[K_{0}\right] \boldsymbol{\delta}=\mathbf{F},
$$

where $\left[K_{0}\right]$ is a linear stiffness matrix; $\boldsymbol{\delta}-$ a displacement vector; $\mathbf{F}-$ a vector of loads applied to the system. 
Due to membrane stresses, actual plate displacements are much smaller than those determined by the theory of linearity. A discrete problem model may be expressed by a system of non-linear algebraic equations:

$$
[K(\boldsymbol{\delta})] \boldsymbol{\delta}-\mathbf{F}=0,
$$

where the stiffness matrix depends on displacements. The iterative Newton-Raphson method [12, 13] was used for solving a system of non-linear equations. According to this approach, a rough solution $\boldsymbol{\delta}_{n}$, where a connection error of external and internal forces $\boldsymbol{\psi}_{n} \neq 0$, was refined by solving a system of linear equations at every iteration:

$$
\begin{gathered}
\Delta \boldsymbol{\delta}_{n+1}=-\left[K_{T}\right]_{n}^{-1} \boldsymbol{\psi}_{n}, \\
{\left[K_{T}\right]=\left[K_{0}\right]+\left[K_{\sigma}\right]+\left[K_{L}\right],}
\end{gathered}
$$

where $\left[K_{T}\right]$ is a tangent stiffness matrix; $\left[K_{\sigma}\right]$ - a matrix of initial stresses; $\left[K_{L}\right]$ - a matrix of large displacements. A connection error $\boldsymbol{\psi}_{n}$ is calculated by the stresses $\boldsymbol{\sigma}_{n}$ :

$$
\boldsymbol{\psi}(\boldsymbol{\delta})=\int_{V}[\bar{B}]^{T} \boldsymbol{\sigma} d V-\mathbf{F}=0,
$$

where $[\bar{B}]$ is a non-linear matrix relating deformations to displacements. A particular case of a geometrically nonlinear problem is the problem of initial stability [11], when matrix $\left[K_{L}\right]=0$.

The dynamic problem is expressed by the equation:

$$
\left[K_{0}\right] \boldsymbol{\delta}+[C] \frac{\partial}{\partial t} \boldsymbol{\delta}+[M] \frac{\partial^{2}}{\partial t^{2}} \boldsymbol{\delta}+\mathbf{F}=0,
$$

where $[C]$ and $[M]$ are damping and mass matrices. A particular dynamic problem is an eigenvalue problem [11, 14], when matrix $[C]=0$ and $\mathbf{F}=0$. This problem is expressed by the equation (6) of the form:

$$
\left[K_{0}\right] \boldsymbol{\delta}=\lambda[M] \boldsymbol{\delta}
$$

where $\lambda$ denotes natural frequencies.

\section{Definition of the finite element}

The stress-strain relation for laminated plates [15, $16]$ is expressed in the following way:

$$
\begin{aligned}
& \mathbf{N}=\left\lfloor D^{p l}\right\rfloor \mathbf{e}^{0}+\left\lfloor D^{p l b}\right\rfloor \mathbf{k}, \\
& \mathbf{M}=\left\lfloor D^{p l b}\right\rfloor \mathbf{e}^{0}+\left\lfloor D^{b}\right\rfloor \mathbf{k},
\end{aligned}
$$

where $\mathbf{N}$ and $\mathbf{M}$ are membrane and bending stresses; $\mathbf{e}^{0}$ denotes midsurface membrane strains; $\mathbf{k}$ - curve vector; $\left\lfloor D^{p l}\right],\left[D^{p l b}\right],\left[D^{b}\right\rfloor$ - accumulative constitutive matrices obtained by combining constitutive matrices of layers [17-19]:

$$
\begin{gathered}
{\left[D^{p l}\right]=\sum_{k=1}^{n}\left[D_{k}\right]\left(z_{k}-z_{k-1}\right),} \\
{\left[D^{p l b}\right]=\frac{1}{2} \sum_{k=1}^{n}\left[D_{k}\right]\left(z_{k}^{2}-z_{k-1}^{2}\right),} \\
{\left[D^{b}\right]=\frac{1}{3} \sum_{k=1}^{n}\left[D_{k}\right]\left(z_{k}^{3}-z_{k-1}^{3}\right),}
\end{gathered}
$$

where $k$ is the layer's number; $\left[D_{k}\right]$ - the $k$-th layer constitutive matrix obtained by transforming the $k$-th layer elasticity characteristics into a global system of the coordinates; $z_{k}$ and $z_{k-1}-$ the coordinates of the $k$-th layer.

The finite element is defined as a combination of bending (DKT) and membrane (CST) finite elements [10]. The DKT element [20] has 3 nodes and 3 degrees of freedom, ie a bending flexure and 2 rotations per node, the interpolation functions of the element should meet only $C^{\circ}$ continuity requirements, because only the first derivatives of the main variables - slopes to the middle surface - appear in the energy functional. The CST element has three nodes, the 1-st order interpolation function and two degrees of freedom - displacements per node.

Structural element matrices are generated based on the matrices of the membrane $(p l)$ and bending $(b)$ elements by combining them as required by the arrangement of the element degrees of freedom to produce a global element matrix.

The vector of degrees of freedom of any node of the element is expressed as:

$$
\boldsymbol{\delta}_{i}=\left\{u_{i}, v_{i}, \omega_{i}, \theta_{x i}, \theta_{y i}, \theta_{z i}\right\}^{T}
$$

where $u_{i}, v_{i}, \omega_{i}$ are node displacements; $\theta_{x i}, \theta_{y i}, \theta_{z i}-$ node rotations about the axis of the coordinates.

The stiffness matrix of the element is as follows:

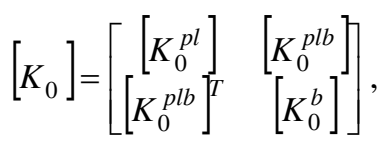

where $\left[K_{0}^{p l}\right],\left\lfloor K_{0}^{b}\right\rfloor$ and $\left[K_{0}^{p l b}\right]$ are membrane, bending and coupling stiffness matrices.

$$
\left[K_{0}^{p l}\right]=A\left[B_{0}^{p l}\right]^{T}\left[D^{p l}\left[B_{0}^{p l}\right],\right.
$$

where $A$ is the area of the element; $\left\lfloor B_{0}^{p l}\right\rfloor-$ a linear membrane geometric matrix [10]. The elements of matrix $\left[K_{0}^{p l}\right]$ are calculated in the following way:

$$
K_{0 i j}^{p l}=\frac{1}{4 A}\left[\begin{array}{ll}
d_{11}^{p l} b_{i} b_{j}+d_{33}^{p l} c_{i} c_{j}+ & d_{12}^{p l} b_{i} c_{j}+d_{13}^{p l} b_{i} b_{j}+ \\
d_{13}^{p l}\left(b_{j} c_{i}+b_{i} c_{j}\right) & d_{23}^{p l} c_{i} c_{j}+d_{33}^{p l} b_{j} c_{i} \\
d_{12}^{p l} b_{j} c_{i}+d_{13}^{p l} b_{i} b_{j}+ & d_{22}^{p l} c_{i} c_{j}+d_{33}^{p l} b_{i} b_{j}+ \\
d_{23}^{p l} c_{i} c_{j}+d_{33}^{p l} b_{i} c_{j} & d_{23}^{p l}\left(b_{i} c_{j}+b_{j} c_{i}\right)
\end{array}\right],
$$


where $d_{i j}^{p l}$ denotes the elements of the accumulative membrane constitutive matrix $\left\lfloor D^{p l}\right] ; b_{i}$ and $c_{i}$ are geometric coefficients. A global matrix is obtained from 9 sections of this type.

$$
\left[K_{0}^{b}\right]=\int_{V}\left[B_{0}^{b}\right]^{T}\left[D^{b}\left[B_{0}^{b}\right] d V\right.
$$

where $\left\lfloor B_{0}^{b}\right\rfloor$ is a linear bending geometric matrix [10].

After the rearrangement [18], any element of matrix $\left\lfloor K_{0}^{b}\right\rfloor$ is expressed in the following way:

$$
\begin{gathered}
K_{0 i j}^{b}=\frac{1}{4 A^{2}} \sum_{i i=1}^{3} \sum_{j j=1}^{3} \sum_{i i i=1}^{3} \sum_{j j j=1}^{3}\left[d_{11}^{b} X_{i, i i} X_{j, j j} b_{i i i} b_{j j j}+\right. \\
d_{22}^{b} Y_{i, i i} Y_{j, j j} c_{i i i} c_{j j j}+ \\
d_{12}^{b}\left(X_{i, i i} Y_{j, j j} b_{i i i} c_{j j j}+X_{j, j j} Y_{i, i i} b_{j j j} c_{i i i}\right)_{+} \\
d_{13}^{b}\left(\begin{array}{l}
X_{i, i i} X_{j, j j} b_{j j j} c_{i i i}+X_{j, j j} Y_{i, i i} b_{i i i} b_{j j j}+ \\
X_{i, i i} X_{j, j j} b_{i i i} c_{j j j}+X_{i, i i} Y_{j, j j} b_{i i i} b_{j j j}
\end{array}\right)+ \\
d_{23}^{b}\left(\begin{array}{l}
X_{i, i i} Y_{j, j j} c_{i i i} c_{j j j}+Y_{i, i i} Y_{j, j j} b_{i i i} c_{j j j}+ \\
X_{j, j j} Y_{i, i i} c_{i i i} c_{j j j}+Y_{i, i i} Y_{j, j j} b_{j j j} c_{i i i}
\end{array}\right)+ \\
d_{33}^{b}\left(\begin{array}{l}
X_{i, i i} X_{j, j j} c_{i i i} c_{j j j}+X_{j, j j} Y_{i, i i} b_{i i i} c_{j j j}+ \\
X_{i, i i} Y_{j, j j} b_{j j j} c_{i i i}+Y_{i, i i} Y_{j, j j} b_{i i i} b_{j j j}
\end{array}\right) \times \times \\
\int \frac{\partial N_{i i z}}{\partial L_{i i i}} \frac{\partial N_{j j z}}{\partial L_{j j j}} d A, \\
i=1,2, \ldots, 9, j=1,2, \ldots, 9,
\end{gathered}
$$

where $d_{i j}^{b}$ denotes the elements of accumulative bending constitutive matrix $\left[D^{b}\right] ; N_{i}$ denotes the interpolation functions; $X_{i, i i}$ and $Y_{i, i i}$ are coefficients of the interpolation functions; $b_{i i i}$ and $c_{i i i}$ stand for geometric coefficients. The values of the integrals $\int_{A} \frac{\partial N_{i i z}}{L_{i i i}} \frac{\partial N_{j j z}}{L_{j j j}} d A$, $\int_{A} N_{i i z} N_{j j z} N_{k k z} N_{l l z} d A, \quad \int_{A} \frac{\partial N_{j j z}}{L_{j j j}} d A, \quad \int_{A} N_{i i z} N_{k k z} \frac{\partial N_{j j z}}{\partial L_{j j j}} d A$ are calculated by the software package Mathematica and stored in the data files. To retrieve them, indices $i i z=\frac{i-3}{3} 3+i i$ and $j j z=\frac{j-1}{3} 3+j j$, calculated accord ing to integer calculation, are used. Then, the elements of the stiffness matrices are numerically synthesised. This method of matrix generation is more advantageous than numerical integration because it is time-saving and allows us to avoid the errors associated with numerical integration.

Flexural strains cause plane deformations, and vice versa (8). This effect is determined by a coupling stiffness matrix $\left[K_{0}^{p l b}\right]$ :

$$
\left[K_{0}^{p l b}\right]=\int_{V}\left[B_{0}^{p l}\right]^{T}\left[D^{p l b}\left[B_{0}^{b}\right] d V .\right.
$$

When the above rearrangement is made, the elements of matrix $\left[K_{0}^{p l b}\right]$ can be expressed as follows:

$$
\begin{gathered}
K_{0 i j}^{p l b}=\frac{1}{4 A^{2}} \sum_{j j=1}^{3} \sum_{j j j=1}^{3}\left[d_{11}^{p l b} b_{i} X_{j, j j} b_{j j j}+\right. \\
d_{12}^{p l b} b_{i} Y_{j, j j} c_{j j j}+d_{23}^{p l b} c_{i} Y_{j, j j} c_{j j j}+ \\
d_{13}^{p l b}\left(c_{i} X_{j, j j} b_{j j j}+b_{i} X_{j, j j} c_{j j j}+b_{i} Y_{j, j j} b_{j j j}\right)+ \\
\left.d_{33}^{p l b}\left(c_{i} X_{j, j j} c_{j j j}+c_{i} Y_{j, j j} b_{j j j}\right)\right] \times \int \frac{\partial N_{j j z}}{\partial L_{j j j}} d A, \\
i=1,3,5, \quad j=1,2, \ldots, 9, \\
K_{0}^{p l b}(i+1) j=\frac{1}{4 A^{2}} \sum_{j j=1}^{3} \sum_{j j j=1}^{3}\left[d_{12}^{p l b} c_{i} X_{j, j j} b_{j j j}+\right. \\
d_{13}^{p l b} b_{i} X_{j, j j} b_{j j j}+d_{22}^{p l b} c_{i} Y_{j, j j} c_{j j j}+ \\
\left.\left.d_{23}^{p l b}\left(b_{i} X_{j, j j} X_{j, j j j}+b_{i} Y_{j, j j} c_{j j j j}\right)_{+}+c_{i} Y_{j, j j} b_{j j j}+b_{i} Y_{j, j j} c_{j j j}\right)\right] \times \int \frac{\partial N_{j j z}}{\partial L_{j j j}} d A, \\
i=1,3,5, j=1,2, \ldots, 9,
\end{gathered}
$$

where $d_{i j}^{p l b}$ denotes the elements of the accumulative coupling constitutive matrix $\left\lfloor D^{p l b}\right\rfloor$.

The matrix of the initial stresses of the element is as follows:

$$
\begin{gathered}
{\left[K_{\sigma}\right]=\left[\begin{array}{cc}
0 & 0 \\
0 & {\left[K_{\sigma}^{b}\right.}
\end{array}\right],} \\
{\left[K_{\sigma}^{b}\right]=\int_{V}[G]^{T}[T][G] d V,}
\end{gathered}
$$

where matrix $[G]$ depends only on the coordinates [14]; $[T]$ is a matrix of the membrane stresses.

When the rearrangement is made [18], a single element of matrix $\left[K_{\sigma}^{b}\right]$ can be expressed as:

$$
\begin{gathered}
{\left[K_{\sigma i j}^{b}\right]=\sum_{i i=1}^{3} \sum_{j j=1}^{3}\left[X_{i, i i} X_{j, j j} T_{x}+Y_{i, i i} Y_{j, j j} T_{y}+\right.} \\
\left.\left(X_{i, i i} Y_{j, j j}+Y_{i, i i} X_{j, j j}\right) T_{x y}\right] \int_{A} N_{i i z} N_{j j z} d A, \\
i=1,2, \ldots, 9, \quad j=1,2, \ldots, 9,
\end{gathered}
$$

where $T_{x}, T_{y}, T_{x y}$ are the membrane stresses.

The stiffness matrix of large displacements of the element is as follows:

$$
\left[K_{L}\right]=\int_{V}\left[\begin{array}{cc}
0 & {\left[K_{L}^{p l b}\right.} \\
{\left[K_{L}^{p l b}\right]^{T}} & {\left[K_{L}^{b}\right]}
\end{array}\right] d V,
$$

where $\left.\mid K_{L}^{b}\right\rfloor$ and $\left[K_{L}^{p l b}\right]$ are non-linear matrices of bending and coupling stiffness. 


$$
\begin{gathered}
{\left[K_{L}^{b}\right]=\int_{V}\left[\left[B_{0}^{b}\right]^{T}\left[D^{p l b}\right]^{T}\left[B_{L}^{b}\right]+\left[B_{L}^{b}\right]^{T}\left[D^{p l b}\left[B_{0}^{b}\right]+\right.\right.} \\
{\left[B_{L}^{b}\right]^{T}\left[D^{p l}\left[B_{L}^{b}\right]\right] d V .} \\
{\left[K_{L}^{b}\right]=\left[K_{L B}^{b}\right]^{T}+\left[K_{L B}^{b}\right]+\left[K_{L C}^{b}\right] .}
\end{gathered}
$$

After the rearrangement [18], the expressions for individual elements of matrices $\left\lfloor K_{L B}^{b}\right\rfloor$ and $\left\lfloor K_{L C}^{b}\right\rfloor$ are as follows:

$$
\begin{aligned}
& K_{L B \quad i, j}^{b}=\frac{1}{2 A} \sum_{k=1}^{9} \sum_{i i=1}^{3} \sum_{j j=1}^{3} \sum_{k k=1}^{3} \sum_{j j j=1}^{3}\left(\boldsymbol{\delta}_{k}^{b} \times\right. \\
& {\left[\left(\begin{array}{l}
X_{i, i i} X_{k, k k} d_{11}^{p l b}+Y_{i, i i} Y_{k, k k} d_{21}^{p l b}+ \\
\left(Y_{i, i i} X_{k, k k}+X_{i, i i} Y_{k, k k}\right) d_{31}^{p l b}
\end{array}\right) X_{j, j j} b_{j j j}+\right.} \\
& \left(\begin{array}{l}
X_{i, i i} X_{k, k k} d_{12}^{p l b}+Y_{i, i i} Y_{k, k k} d_{22}^{p l b}+ \\
\left(Y_{i, i i} X_{k, k k}+X_{i, i i} Y_{k, k k}\right) d_{32}^{p l b}
\end{array}\right) Y_{j, j j} c_{j j j}+ \\
& \left(\begin{array}{l}
X_{i, i i} X_{k, k k} d_{13}^{p l b}+Y_{i, i i} Y_{k, k k} d_{23}^{p l b}+ \\
\left(Y_{i, i i} X_{k, k k}+X_{i, i i} Y_{k, k k}\right) d_{33}^{p l b}
\end{array}\right) \times \\
& \left.\left.\left(X_{j, j j} c_{j j j}+Y_{j, j j} b_{j j j}\right)\right] \times \int_{A} N_{i i z} N_{k k z} \frac{\partial N_{j j z}}{\partial L_{j j j}} d A\right), \\
& i=1,2, \ldots, 9, j=1,2, \ldots, 9 \text {. } \\
& K_{L C i, j}^{b}=\sum_{k=1}^{9} \sum_{l=1}^{9} \sum_{i i=1}^{3} \sum_{j j=1}^{3} \sum_{k k=1}^{3} \sum_{l l=1}^{3}\left(\boldsymbol{\delta}_{k}^{b} \boldsymbol{\delta}_{l}^{b} \times\right. \\
& {\left[X_{k, k k} X_{l, l l}\left(\begin{array}{l}
X_{i, i i} X_{j, j j} d_{11}+X_{i, i i} Y_{j, j j} d_{13}+ \\
Y_{i, i i} X_{j, j j} d_{31}+Y_{i, i i} Y_{j, j j} d_{33}
\end{array}\right)+\right.} \\
& Y_{k, k k} Y_{l, l l}\left(\begin{array}{l}
Y_{i, i i} Y_{j, j j} d_{22}+Y_{i, i i} X_{j, j j} d_{23}+ \\
X_{i, i i} Y_{j, j j} d_{32}+X_{i, i i} X_{j, j j} d_{33}
\end{array}\right)+ \\
& \left.X_{k, k k} Y_{l, l l}\left(\begin{array}{l}
X_{i, i i} Y_{j, j j} d_{12}+Y_{i, i i} X_{j, j j} d_{21}+ \\
X_{i, i i} X_{j, j j} d_{31}+Y_{i, i i} Y_{j, j j} d_{32}+ \\
Y_{i, i i} Y_{j, j j} d_{23}+X_{i, i i} Y_{j, j j} d_{33}+ \\
X_{i, i i} X_{j, j j} d_{13}+Y_{i, i i} X_{j, j j} d_{33}
\end{array}\right)\right] \times \\
& \left.\int_{A} N_{i i z} N_{j j z} N_{k k z} N_{l l z} d A\right), \\
& i=1,2, \ldots, 9, j=1,2, \ldots, 9 \text {. } \\
& {\left[K_{L}^{p l b}\right]=\int_{V}\left[B_{0}^{p l}\right]^{T}\left[D^{p l} \llbracket B_{L}^{b}\right] d V,}
\end{aligned}
$$

where $\left\lfloor B_{L}^{b}\right\rfloor$ is a non-linear geometric bending matrix [11].

After the rearrangement [18], the following expressions are obtained for the elements of matrix $\left[K_{L}^{p l b}\right]$ :

$$
\begin{aligned}
& K_{L}^{p l b}{ }_{i, j}=\frac{1}{2 A} \sum_{k=1}^{9} \sum_{j j=1}^{3} \sum_{k k=1}^{3}\left[\boldsymbol{\delta}_{k}^{b} \times\left(X_{j, j j} X_{k, k k} \times\right.\right. \\
& \left(b_{l} d_{11}^{p l}+c_{l} d_{31}^{p l}\right)+Y_{j, j j} Y_{k, k k}\left(b_{l} d_{12}^{p l}+c_{l} d_{32}^{p l}\right)+ \\
& \left.\left(Y_{j, j j} X_{k, k k}+X_{j, j j} Y_{k, k k}\right)\left(b_{l} d_{13}^{p l}+c_{l} d_{33}^{p l}\right)\right) \times \\
& \int_{A} N_{j j z} N_{k k z} d A, \\
& K_{L}^{p l b}(i+1), j=\frac{1}{2 A} \sum_{k=1}^{9} \sum_{j j=1}^{3} \sum_{k k=1}^{3} \boldsymbol{\delta}_{k}^{b} \times\left(X_{j, j j} X_{k, k k} \times\right. \\
& \left(b_{l} d_{31}^{p l}+c_{l} d_{21}^{p l}\right)+Y_{j, j j} Y_{k, k k}\left(b_{l} d_{32}^{p l}+c_{l} d_{22}^{p l}\right)+ \\
& \left.\left(Y_{j, j j} X_{k, k k}+X X_{j, j j} Y_{k, k k}\right)\left(b_{l} d_{33}^{p l}+c_{l} d_{23}^{p l}\right)\right) \times \\
& \int_{A} N_{j j z} N_{k k z} d A, \\
& i=1,3,5, \quad l=1,2,3, \quad j=1,2, \ldots, 9,
\end{aligned}
$$

where $\boldsymbol{\delta}_{k}^{b}$ is the displacement or turn of the bending element node (10).

A connection error of external and internal forces (5) is calculated in the following way:

$$
\left.\boldsymbol{\Psi}_{i}=\left\{\begin{array}{c}
\frac{1}{2}\left[K_{L}^{p l b}\right] \boldsymbol{\delta}_{i}^{b} \\
\left.\left[K_{L}^{p l b}\right] \boldsymbol{\delta}_{i}^{p l}+\frac{1}{2}\left[K_{L B}^{b}\right]^{T} \boldsymbol{\delta}_{i}^{b}+\right) \\
{\left[K_{L B}^{b}\right] \boldsymbol{\delta}_{i}^{b}+\frac{1}{2}\left[K_{L C}^{b}\right] \boldsymbol{\delta}_{i}^{b}}
\end{array}\right)\right\},
$$

where $i$ is the iteration; matrices $\left[K_{L}^{p l b}\right],\left\lfloor K_{L B}^{b}\right\rfloor$ and $\left\lfloor K_{L C}^{b}\right\rfloor$ are generated according to the calculated displacements $\boldsymbol{\delta}_{i}^{p l}$ and $\boldsymbol{\delta}_{i}^{b}$ in iteration $(i-1)$.

Stresses are calculated in this way:

$$
\boldsymbol{\sigma}=\left\{\begin{array}{c}
\boldsymbol{\sigma}_{0}^{p l} \\
\boldsymbol{\sigma}_{0}^{b}
\end{array}\right\}+\left\{\begin{array}{c}
\boldsymbol{\sigma}_{L}^{p l} \\
\boldsymbol{\sigma}_{L}^{b}
\end{array}\right\},
$$

where $\boldsymbol{\sigma}_{0}$ and $\boldsymbol{\sigma}_{L}$ are vectors of linear and non-linear stresses.

$$
\begin{gathered}
\boldsymbol{\sigma}_{0}^{p l}=\left[D^{p l}\right]\left[B_{0}^{p l}\right] \boldsymbol{\delta}^{p l}+\left[D^{p l b}\right]\left[B_{0}^{b}\right] \boldsymbol{\delta}^{b}, \\
\boldsymbol{\sigma}_{0}^{b}=\left[D^{p l b}\right]^{T}\left[B_{0}^{p l}\right] \boldsymbol{\delta}^{p l}+\left[D^{b}\right]\left[B_{0}^{b}\right] \boldsymbol{\delta}^{b}, \\
\boldsymbol{\sigma}_{L}^{p l}=\frac{1}{2}\left[D^{p l}\right]\left[B_{L}^{b}\right] \boldsymbol{\delta}^{b}, \\
\boldsymbol{\sigma}_{L}^{b}=\frac{1}{2}\left[D^{p l b}\right]^{T}\left[B_{L}^{b}\right] \boldsymbol{\delta}^{b} .
\end{gathered}
$$

\section{Numerical examples}

The quality of the finite element developed for solving geometrically linear and non-linear static and eigenvalue problems will be demonstrated by standard 
tests of bending plates. Square symmetrical and nonsymmetrical laminated plates which were fixed or hinged were tested by applying concentrated or distributed loads. The calculation results were compared as dimensionless values.
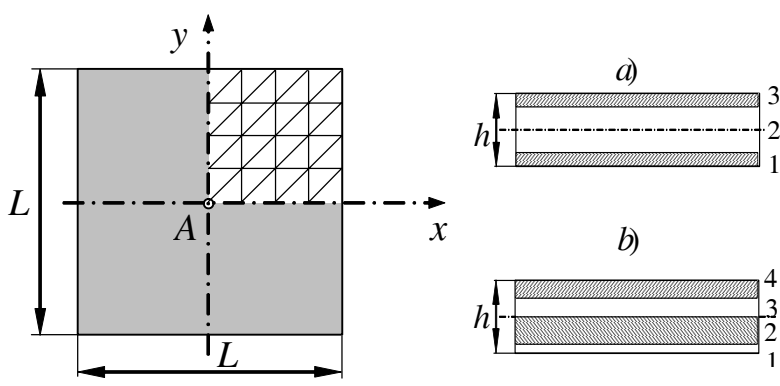

Fig 1. Computational schema: a) symmetrical laminated plate; b) non-symmetrical laminated plate

\subsection{A linear problem}

Test 1. A hinged square three-layer plate (Fig 1a) subjected to uniformly distributed pressure $q=0,001$ was considered. The plate was calculated for 3 different materials making the intermediate layer. The difference between the material properties of the intermediate and upper and lower layers is 1 (further (1:1:1)), 10 (further $(1: 10: 1))$ and 50 (further (1:50:1)) times. The thickness of the layers is $h_{1}=10,0, h_{2}=80,0$ and $h_{3}=10,0$, respectively; $L=1000,0$. The orientation of the orthotropy axes of the layers is $0 / 45 / 0$. The data on the properties of the material of the layers are given in Table 1.

Table 1. A symmetrical composite: properties of the materials of the layers

\begin{tabular}{l|c|c|c|c}
\hline \multirow{2}{*}{ Layer No } & Modulus of elasticity & $\begin{array}{c}\text { Shear } \\
\text { modulus }\end{array}$ & $\begin{array}{c}\text { Poisson's } \\
\text { ratio }\end{array}$ \\
\cline { 2 - 5 } & $E_{11}$ & $E_{22}$ & $G_{12}$ & $v_{12}, v_{21}$ \\
\hline $\mathbf{1 , 3}$ & 3,4156 & 1,7931 & 1,0 & 0,44 \\
\hline a) laminated orthotropic material (1:1:1) \\
\hline $\mathbf{2}$ & 3,4156 & 1,7931 & 1,0 & 0,44 \\
\hline b) properties of the material of the layer (1:10:1) \\
\hline $\mathbf{2}$ & 0,34156 & 0,17931 & 0,1 & 0,44 \\
\hline c) properties of the material of the layer (1:50:1) \\
\hline $\mathbf{2}$ & 0,06831 & 0,03586 & 0,02 & 0,44 \\
\hline
\end{tabular}

One fourth of the plate was modelled by 72,128 and 200 finite elements DKT_CST. A comparison of the calculation results obtained at the deflection point A (Fig 1) by using the DST element and analytical solutions [21] is provided in Table 2 .

As shown in Table 2, the results obtained by using the element DKT_CST are monotonically approaching the accurate analytical and DST-based solutions. The accurate deflection values were obtained by subdividing a quarter of the plate into 128 elements.
Table 2. Central deflection of symmetric layered plate

\begin{tabular}{c|c|c|c|c|c}
\hline \multirow{2}{*}{ Test } & \multicolumn{5}{|c}{ Solutions $\omega$} \\
\cline { 2 - 6 } & \multicolumn{3}{|c}{ (according to the number of elements) } \\
\cline { 2 - 6 } & DST & Ana- & \multicolumn{3}{|c}{ DKT_CST } \\
\cline { 2 - 6 } & $\mathbf{7 2}$ & lytical & $\mathbf{7 2}$ & $\mathbf{1 2 8}$ & $\mathbf{2 0 0}$ \\
\hline $1: 1: 1$ & 166,94 & 168,38 & 166,93 & 167,56 & 167,78 \\
\hline $1: 10: 1$ & 30,96 & 31,24 & 30,955 & 31,071 & 31,088 \\
\hline $1: 50: 1$ & 6,77 & 6,76 & 6,702 & 6,723 & 6,729 \\
\hline
\end{tabular}

Test 2. Two laminated non-symmetrical square fixed and hinged plates were considered. The plates consisted of 4 layers (Fig 1b) of overall thickness $h=0,04$ and layers thickness $h_{1}=0,011, \quad h_{2}=0,09, \quad h_{3}=0,1, \quad h_{4}=0,1$, respectively, and $L=1,0$. The data on the properties of the material of the layers are presented in Table 3 . The orientation of the orthotropy axes of the layers is 0/90/0/90. The plates were acted upon by a concentrated force $P=100,0$ applied at the point A.

Table 3. A non-symmetrical composite: properties of the materials of the layers

\begin{tabular}{c|c|c|c|c}
\hline \multirow{2}{*}{$\begin{array}{c}\text { Layer } \\
\text { No }\end{array}$} & \multicolumn{2}{|c|}{ Modulus of elasticity } & $\begin{array}{c}\text { Shear } \\
\text { modulus }\end{array}$ & $\begin{array}{c}\text { Poisson's } \\
\text { ratio }\end{array}$ \\
\cline { 2 - 5 } & $E_{11}$ & $E_{22}$ & $G_{12}$ & $v_{12}, v_{21}$ \\
\hline $\mathbf{1}$ & $3,0 \times 10^{8}$ & $3,0 \times 10^{8}$ & $1,2 \times 10^{8}$ & 0,25 \\
\hline $\mathbf{2 , 3 , 4}$ & $3,0 \times 10^{7}$ & $3,0 \times 10^{7}$ & $1,2 \times 10^{7}$ & 0,25 \\
\hline
\end{tabular}

A fourth of the plate was modelled by $8,18,32,50$, 72, 128 and 200 finite elements DKT_CST. A comparison of the calculation results obtained by using the TRIPLT element at the deflection point $\mathrm{A}$ is provided in Fig 2. The solutions based on the use of the element TRIPLT were obtained when the calculations of the fourth part of the plate divided into 18 elements had been made.

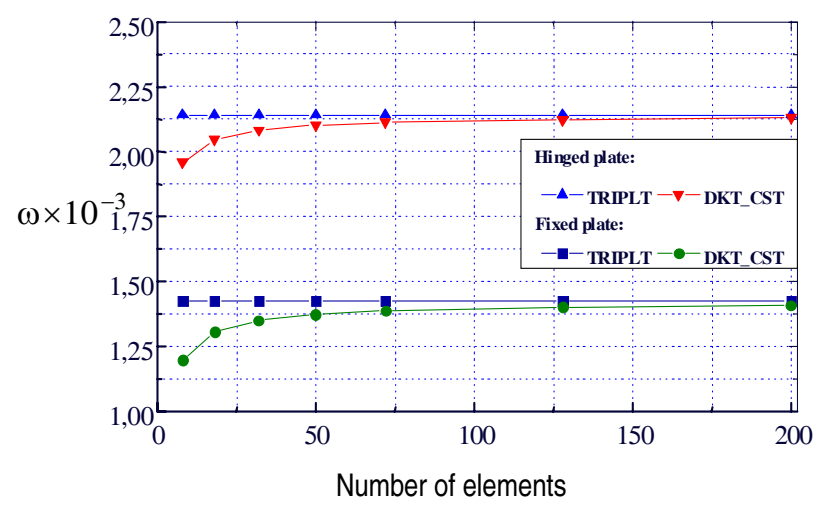

Fig 2. Convergence of values

One per cent difference between the solutions based on the use of TRIPLT and DKT_CST elements was obtained for a hinged plate by subdividing one-fourth of the plate into 128 DKT_CST elements. The results of similar accuracy were obtained for a fixed plate by subdividing one-fourth of the plate into 200 DKT_CST elements. 


\subsection{A geometrically non-linear problem}

The calculations were made for a fixed nonsymmetrical laminated square plate (Fig 1b). The plate consisted of 3 layers of the thickness: $h_{1}=0,1$, $h_{2}=0,65, h_{3}=0,25 ; L=10,0$. The data on the properties of the material of the layers are presented in Table 4. The orientation of the orthotropy axes of the layers was 0/90/0. The deflection of the plate at point A was considered by changing the value of the concentrated load $P$ from $0,01 h$ to $0,7 h$.

Table 4. Properties of the materials of the layers

\begin{tabular}{c|c|c|c|c}
\hline \multirow{2}{*}{$\begin{array}{c}\text { Layer } \\
\text { No }\end{array}$} & \multicolumn{2}{|c|}{ Modulus of elasticity } & $\begin{array}{c}\text { Shear } \\
\text { modulus }\end{array}$ & $\begin{array}{c}\text { Poisson's } \\
\text { ratio }\end{array}$ \\
\cline { 2 - 5 } & $E_{11}$ & $E_{22}$ & $G_{12}$ & $v_{12}, v_{21}$ \\
\hline $\mathbf{1 , 3}$ & 3,4156 & 1,7931 & 1,0 & 0,44 \\
\hline $\mathbf{2}$ & 1,7931 & 3,4156 & 1,0 & 0,44 \\
\hline
\end{tabular}

One-fourth of the plate was modelled using 128 DKT_CST finite elements. The deflections of the plate observed at point A were compared with the solutions obtained for the triangular element SHELL91 by calculating plates subdivided into 128 elements, using the software package ANSYS.

The values of deflections are given in Fig 3 in terms of the overall plate thickness $h$.

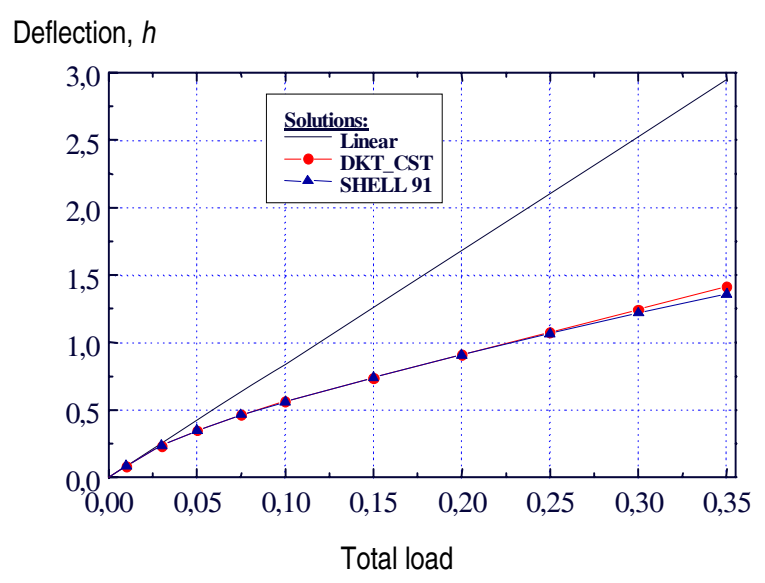

Fig 3. Central deflection of the plate

The calculations show that the membrane strains occur when the deflection at point A is more than $0,2 h$. When the linear deflection was $0,25 h$, the difference between the non-linear solutions obtained by using the elements DKT_CST and SHELL91 made 0,08 \%. Then, the linear deflection reached $2,5 h$, while the difference between the non-linear solutions was $2 \%$.

\subsection{The eigenvalue problem}

The calculations were made for a non-fixed square three-layer plate (Fig 1). The whole plate was analysed to take into account all forms of oscillations, while the conditions of symmetry were neglected. The thickness of the plate layers was $h_{1}=0,1, \quad h_{2}=0,15, h_{3}=0,25$, respec- tively; $L=4,0 ; \quad$ moduli of elasticity were $E_{11}=E_{22}=2,0 \times 10^{6} ; \quad$ Poisson's ratio was $v_{12}=v_{21}=0,3$; shear moduli were $G_{12}=0,77 \times 10^{6}$ and density $\rho=1000$. The orientation of the layers orthotropy axes was $0 / 0 / 0$.

The plate was modelled using 8, 32, 72, 128 and 200 DKT_CST elements. A comparison of the first three calculation results relating to non-zero eigen frequencies with analytical solutions is presented in Fig 4. The first six zero forms of the plate match the movements of a solid body. Non-zero forms are shown in Fig 5 .

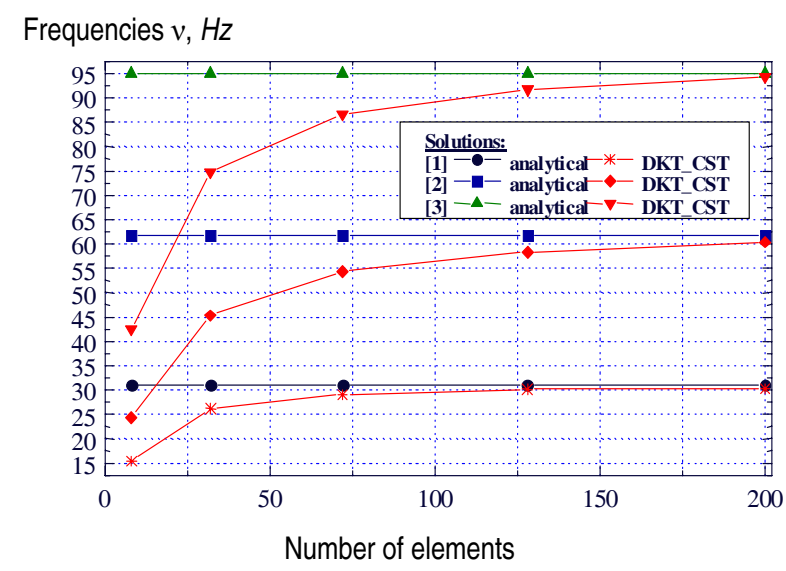

Fig 4. Convergence of the first three non-zero frequencies
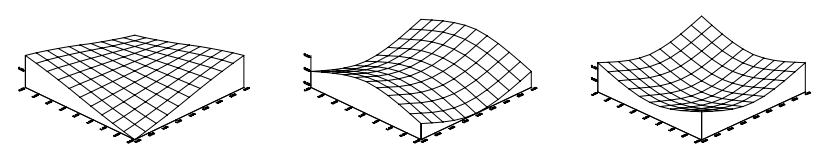
a) $v=30,66 \mathrm{~Hz}$
b) $v=60,36 \mathrm{~Hz}$
c) $v=94,27 \mathrm{~Hz}$

Fig 5. Forms and frequencies of the first three non-zero natural oscillations

The convergence curves of the results presented in Fig 4 demonstrate that the solutions obtained using DKT_CST element quickly converge towards an accurate solution. The accurate value of the first eigen frequency was obtained by subdividing the plate into 128 elements.

\section{Conclusions}

All finite element structural matrices were generated using an effective analytical-numerical method of matrix development. This helped to avoid difficulties and errors involved in currently used numerical integration, to increase the accuracy of calculations and to obtain analytical expressions which can be easily implemented in software programmes for generating the element stiffness, initial stress and large displacement matrices and vectors of stresses.

The suggested finite element was numerically tested by comparing the results obtained in solving geometrically linear and non-linear static as well as eigenvalue problems with the well-known analytical solutions or the data obtained by applying the finite element method. The 
analysis of the numerical tests shows that the element has good convergence characteristics as well as being sufficiently accurate and saving the time of calculation.

The suggested finite element can be used for modelling laminated anisotropic bending plates, their separate zones or beams when shear strains are insignificant.

The program developed for modelling laminated bending plates can be used in design offices and at industrial enterprises.

\section{References}

1. Damkilde, L.; Gronne, M. An improved triangular element with drilling rotations. In: Proc of the 15th Nordic Seminar on Computational Mechanics, Aalborg, Denmark, 2002, p. 135-138.

2. Duan, H. Y.; Liang, G. P. A locking-free ReissnerMindlin quadrilateral element. Mathematics of Computation, 73, 2004, p. 1655-1671.

3. Nikolic, Z.; Mihanovic, A. Thin plate quadrilateral element with independent rotational DOF. International Journal for Engineering Modelling, 16(3), 2003, p. 256269.

4. Piltner, R.; Joseph, D. S. A mixed finite element for plate bending with eight enhanced strain modes. Communications in Numerical Methods in Engineering, 17(7), 2001, p. 443-454.

5. Sheikh, A. H.; Haldar, S.; Sengupta, D. A high precision shear deformable element for the analysis of laminated composite plates of different shapes. Composite Structures, 55(3), 2002, p. 329-336.

6. Chakrabarti, A. A new plate bending element based on higher order shear deformation theory for the analysis of composite plates. Finite Element in Analysis and Design, 39(9), 2003, p. 883-903.

7. Auricchio, F.; Lovadina, C.; Sacco, E. Analysis of mixed finite elements for laminated composite plates. Computer Methods in Applied Mechanics and Engineering, 190(3536), 2001, p. 4767-4783.
8. Alfano, G.; Auricchio, F.; Rosati, L. MITC finite elements for laminated composite plates. International Journal for Numerical Methods in Engineering, 50(3), 2001, p. 707738.

9. Lakshminarayana, H. V.; Sridhara Murthy, S. A. Shearflexible triangular finite element model for laminated composite plates. International Journal for Numerical Methods in Engineering, 20(4), 1984, p. 591-623.

10. Belevičius, R.; Michnevič, E. A laminated DKT element: modal analysis. Aviation (Aviacija), 4, 2000, p. 94-99 (in Lithuanian).

11. Zienkiewicz, O. C.; Taylor, R. L. The finite element method. New York: McGraw-Hill, Vol 2, 1991. 790 p.

12. Crisfield, M. A. Non-linear finite element analysis of solids and structures. New York: John Wiley \& Sons, Inc, 1991. $345 \mathrm{p}$.

13. Hinton, E. Introduction to nonlinear finite element analysis. Glasgow: Bell and Bain Ltd., 1992. 380 p.

14. Bathe, K. J.; Wilson, E. L. Numerical method in finite element analysis. New Jersey: Prentice-Hall Inc, 1976. $524 \mathrm{p}$.

15. Barbero, E. J. Introduction to composite materials design. London: Taylor \& Francis, Inc, 1998. 352 p.

16. Reddy, J. N. Mechanics of laminated composite plates:: theory and analysis. $2^{\text {nd }}$ ed. London: CRC Press, LLC, 2003. 856 p.

17. Jones, R. M. Mechanics of composite materials. $2^{\text {nd }}$ ed. London: Taylor \& Francis, Inc, 1998. 519 p.

18. Belevičius, R. Computer algebra in finite element method. Vilnius: Technika, 1994. 154 p.

19. Belevičius, R.; Rusakevičius, D. The optimization of the composite bending plates. Journal of Civil Engineering and Management, 8(3), 2002, p. 143-152.

20. Batoz, J. L.; Bathe, K. J.; Ho, L. W. A study of three-node triangular plate bending elements. International Journal for Numerical Methods in Engineering, 15(12), 1980, p. 1771-1812.

21. Birger, I. A.; Panovko, J. G. Strength, stability, vibrations (Прочность, устойчивость, колебания). Moscow: Mashinostrojenije, Vol 3, 1968. 567 p. (in Russian).

\section{[RANKIS SLUOKSNIUOTŲ LENKIAMŲ PLOKŠTELIŲ MODALINEI ANALIZEI}

\section{E. Michnevič}

\section{Santrauka}

Efektyvaus diskretinès Kirchhofo teorijos trikampio baigtinio elemento DKT pagrindu suformuluotas naujas baigtinis elementas lenkiamoms daugiasluoksnèms plokštelèms modeliuoti. Plokštelès gali būti sudarytos iš kelių bet kokia tvarka išdèstytų sluoksnių, kurių medžiaga gali būti skirtinga bei ortotropinè. Naujas trikampis baigtinis elementas turi 6 laisvumo laipsnius kiekviename mazge: 3 linijinius poslinkius ir 3 posūkius apie koordinačių ašis. Elemento matematinis modelis apima visus deformacijų ir įtempių efektus tiek elemento plokštumoje, tiek statmena šiai plokštumai kryptimi, išskyrus šlytị. Elementas gali būti naudojamas sluoksniuotoms lenkiamoms plokštelèms arba sijoms, kurioms šlyties ịtaka nežymi, skaičiuoti. Darbe pateikti skaitiniai pavyzdžiai, gauti rezultatai palyginti su žinomais analitiniais ir skaitiniais sprendiniais.

Reikšminiai žodžiai: laminatai, kompozitai, kompozitinės struktūros, sluoksniuotosios plokštelès, tiesinè analize, netiesinè analizè, baigtinis elementas.

Edvard MICHNEVIČ. Assoc Prof of Dept of Engineering Mechanics, Vilnius Gediminas Technical University, Lithuania. PhD (2001) at VGTU. Research interests: finite element methods, modelling laminated structures. 